\title{
O. Kolomitssev, V. Pustovarov
}

\section{FORMAL REPRESENTATION OF THE PIXEL-BY-PIXEL CLASSIFICATION PROCESS USING A MODIFIED WANG-MENDEL NEURAL NETWORK}

The subject of research in the article are the processes of formalization of the pixel-by-pixel classification problem using the modified fuzzy neural production network of Wang-Mendel for segmentation of urban structures in the automated analysis of space and aerial photographs of the city. The purpose of the work is to develop the architecture of the modified fuzzy neural production network of Wang-Mendel as a classifier for image segmentation to increase the values of efficiency and reliability of urban monitoring. The following tasks are solved in the article: analysis of possibilities of Wang-Mendel network modification based on representation of membership functions in terms of interval fuzzy sets of the second type (IFST2) and realization of phasing, aggregation and activation operations using IFST 2 operations, development of the architecture of the modified fuzzy neural production network of WangMendel as a classifier for image segmentation. The following methods and models are used: methods and models of fuzzy set theory (fuzzy Wang-Mendel neural network, interval fuzzy sets of the second type), methods and models of deep learning methodology (convolutional neural network for image segmentation (auto coder) U-net). The following results were obtained: the use of a fuzzy Wang-Mendel neural network as a classifier of a modified U-Net decoder based on the representation of membership functions in IFST2 and the implementation of phasing, aggregation and activation operations using operations on IFST2; introduction of an additional operation of type reduction in the phase of dephasification of the original variable based on the classical method of the center of gravity (centroid); introduction of several outputs of the network to recognize the appropriate number of classes (subclasses) of the subject area. To do this, the third layer is represented as a set of several pairs of adder neurons, and the fourth implements several normalizing neurons, the number of which corresponds to the number of pairs of the third layer. Conclusions: the use in the architecture of a convolutional neural network for segmentation of U-net images as a classifier of the modified fuzzy neural production network of Wang-Mendel will provide an additional increase in the accuracy of pixel-by-pixel classification of certain objects. Instead of fuzzy sets of the first type (FST1) in this network IFST2 are used. The proposed IFST2, on the one hand, provide a formalization of more additional degrees of uncertainty compared to FST1, on the other hand, are "implemented" in the development of fuzzy systems (models) and have less computational complexity, compared to fuzzy sets of the second type (FST2).

Keywords: segmentation; classification; fuzzy set of the second type; fuzzy neural network; production model.

\section{Introduction}

At present, the rapid growth of urban areas requires the improvement of management systems. In order to effectively manage a modern city, it is necessary to obtain timely data, which is ensured by conducting appropriate monitoring.

The main requirements for monitoring are efficiency and reliability in obtaining information. It is possible to increase the value of efficiency and reliability of urban monitoring through the use of data from automated analysis of space and aerial photographs of the city.

When monitoring, the most important thing is to identify changes in the urban environment and analyze the causes of their occurrence. The most common changes in the urban environment that can be monitored by automated analysis of space and aerial photographs are the demolition and erection of buildings, changes in the area of greenery, construction or expansion of roads, detection of illegal construction, etc.

The first step in the analysis of space and aerial photographs, with automated monitoring of the urban environment, it is possible to consider the stage of automatic recognition of various objects in the field. The most effective for solving the problems of semantic segmentation in the framework of the theory of deep learning are various implementations of the auto encoder.

In this study, the U-Net network is used as the basic architecture of a deep neural network for the segmentation of urban structures in digital space and aerial photographs in automated monitoring of the urban environment. The classifier of the classic U-Net are fully connected layers, which are converted into a convolution.

However, studies show that fuzzy neural networks provide higher recognition accuracy compared to classical fully connected networks [1].

Thus, an actual scientific task is the development of neural network architecture, as a classifier of which it is possible to use a modified fuzzy Wang-Mendel neural network [1].

\section{Analysis of publications}

Currently, there are a large number of publications on the development of neural network architecture for the segmentation of objects in images for different purposes [4-12]. At the same time, the issues of integrated application of the modified fuzzy Wang-Mendel neural network for segmentation of urban structures in digital space and aerial photographs in automated monitoring of the urban environment, including the use of fuzzy neural networks, are not actually considered and require further research.

The aim of the article is to develop the architecture of the modified fuzzy neural production network of Wang-Mendel as a classifier for image segmentation and increase the values of efficiency and reliability of urban monitoring.

\section{Main part}

The classical fuzzy neural production network of Wang-Mendel implements a fuzzy production model according to the rules, the conditions and conclusions of 
which are formed on the basis of a fuzzy set of type 1. In this case, the membership functions of all fuzzy sets are Gaussian. In this regard, the output signal of the WangMendel network can be calculated according to the expressions [13-15]:

$$
\begin{array}{r}
y_{\text {class }}(x)=\frac{\sum_{i=1}^{M} c_{i} \prod_{j=1}^{N} \mu_{i j}\left(x_{j}\right)}{\sum_{i=1}^{M} \prod_{j=1}^{N} \mu_{i j}\left(x_{j}\right)}, \\
\mu_{i j}\left(x_{j}\right)=\exp \left[-\left(\frac{x_{j}-a_{i j}}{b_{i j}}\right)^{2}\right],
\end{array}
$$

where $x_{j}$ is an input signal; $c_{i}$ is the center of the width of the Gaussian function, which represents the membership function of a fuzzy set of rule conclusions; $\mu_{i j}$ is a Gaussian function with the parameters of the mathematical expectation, which determines the center $a_{i j}$, and the scatter parameters, which are determined by the standard deviation, which represents the membership function of a fuzzy set of conditions of the rules; $N$ - the number of input network variables; $M$ - the number of neurons in the first layer that realizes the fuzzification of input variables.

Directly, the structure of the Wang-Mendel network is a four-layer neural network in which:

- in the first layer the fuzzification of input variables is performed;

- in the second layer the aggregation of activation values of the fuzzy production rule condition is carried out;

- in the third layer activation of conclusions of rules of withdrawal is carried out;

- in the fourth layer, consisting of one neuron, dephasification of the output variable and the formation of the output signal.

According to the network structure and expressions (1), (2), the first and third layers are parametric.

The fuzzy inference algorithm, which is implemented by this fuzzy neural production network, is based on the following main provisions:

- input variables are clear;

- the membership functions of all fuzzy sets are represented by the Gaussian function;

- accumulation of activated rules is not carried out.

Modification of the classical Wang-Mendel network to solve the problem for pixel-by-pixel classification of certain objects is carried out with the following help:

1) representation of membership functions in terms of IFST2 and implementation of fuzzification, aggregation and activation operations using operations on IFST2;

2) the introduction of an additional type reduction operation in the phase of dephasification of the original variable based on the classical method of the center of gravity (centroid);

3) introduction of several network outputs to recognize the appropriate number of classes (subclasses) of certain objects. To do this, the third layer is presented as a set of several pairs of neurons-adders, and the fourth implements several neurons-normalizers, the number of which corresponds to the number of pairs of the third layer.

In the general case, the fuzzy production rule for the modified fuzzy Wang-Mendel neural production network can be represented as follows [14]:

$$
R: \text { IF } \beta_{1} \text { is } \alpha_{1} A N D \text {... AND } \beta_{n} \text { is } \alpha_{n} \text { THEN } \beta_{n+1}=c_{j}^{p},
$$

where $\beta_{1}$ is the name of the input data (in the form of a clear (in some cases) or linguistic value (LV)) specified by the tuple $\left\langle\beta_{1}, T_{i}, X_{i}, M_{i}\right\rangle, i=1, \ldots, n$ and $n$ is a number of input variables; $T_{i}=\left\{a_{i}\right\} \quad-$ a set of values (terms) of the input LV of the rule $R$, each of which is the name of a fuzzy value $(\mathrm{FV})$ to describe the values of the recognition parameters of compact (point) objects of air reconnaissance; $X_{i}$ - the range of values of the $\mathrm{FV}$, the names of which are included in $T_{i}, M_{i}$ - semantic procedure that matches fuzzy set to the value of the LV. The syntactic procedure of generating new values for LV $G_{i}$ is not used, because all LV values within the proposed approach are determined at the stage of formation of the rule base; $\alpha_{i}$ is the value of the term of the input LV in the form of the name FV (linguistic value of the object recognition parameter), given by the tuple $\left\langle\alpha_{i}, X_{i}, \tilde{A}\right\rangle, i=1, \ldots, n, \tilde{A} \subseteq X_{i} ; \tilde{A}=\left\{x, \mu_{\tilde{A}}(x)\right\}-$ IFST2 on the set $X_{i}$, which describes the possible values that can take FV $\alpha_{i} \in T_{i} ; \beta_{n+1}$ is the name of the original LV, given by the tuple $\left\langle\beta_{n+1}, T_{n+1}, Y, M_{n+1}\right\rangle, Y$ is the range of values of terms, the names of which are included in $T_{n+1}$, representing the number of the recognized class (subclass) of the object; $M_{n+1}$ is a semantic procedure that corresponds to the value of LV one-point fuzzy set; $c_{j}^{p}$ is the value of the term source LV in the form of the name or class number from the set $C_{p}=\left\{c_{j}^{p}\right\}, j=1, \ldots, m$, where $m$ is the number of classes (subclasses) of compact (point) objects.

Formally, IFST2 means a fuzzy set of type 2, or all secondary degrees $f_{x}(u)=\mu_{\tilde{A}}(x, u)$ are equal to 1 and are represented as follows:

- in the case of continuous (infinite) $X$ and $J_{x}$, as [15]:

$$
\tilde{A}=\int_{x u} \int_{u} \frac{1}{(x, u)}, u \in J_{x} \subseteq U=[0,1], x \in X,
$$

or:

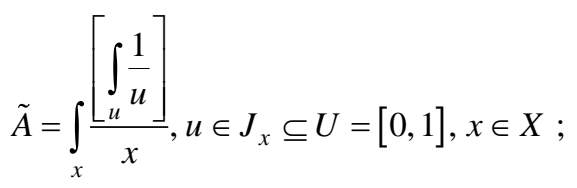

- in the case of discrete (finite) $X$ and $J_{x}$, as: 


$$
\tilde{A}=\sum_{j=1}^{N} \frac{\left[\sum_{i=1}^{M_{j}} \frac{1}{u_{i}}\right]}{x_{j}}, u \in J_{x} \subseteq U=[0,1], x \in X
$$

or as a set:

$$
\tilde{A}=\left\{((x, u), 1) \mid \forall x \in X, \forall u \in J_{x} \subseteq U=[0,1]\right\},
$$

where $x$ is a first variable $x \in X ; X$ is the universal set of objects of the visual field; $u$ is the second variable $u \in J_{x} ; J_{x}$ is a primary affiliation $J_{x} \subseteq U ; U$ - area of definition of primary affiliation $U=[0,1]$; $f_{x}(u)=\mu_{\tilde{A}}(x, u)-$ secondary degree, which is equal to 1.

There are two main methods of formal representation of IFST2 - methods of vertical and wavy section $[8,9]$. To represent the membership functions of the modified fuzzy Wang-Mendel neural production network in terms of IFST2, it is possible to consider the basic concept of the occupied area of uncertainty.

The aggregation of all IFST2 primers is the footprint of uncertainty $(F O U)$ and can be represented as $[8,9]$ :

$$
\operatorname{FOU}(\tilde{A})=\bigcup_{\forall x \in X} J_{x}=\left\{(x, u) ; u \in J_{x} \subseteq[0,1]\right\} .
$$

The definition of $F O U$ for IFST2 and total FST2 is the same. However, for IFST2 the occupied area of uncertainty is of particular importance. This is due to the fact that, since the secondary stages of IFST2 do not transmit new information about the additional stages of uncertainty, it can be assumed that the $F O U$ is a complete description of IFST2.

For IFST2, the primary membership can be represented as follows $[8,9]$ :

$$
J_{x}=\left[\bar{\mu}_{\tilde{A}}(x), \underline{\mu}_{\tilde{A}}(x)\right],
$$

where $\bar{\mu}_{\tilde{A}}(x)$ - the value of the upper membership function denoted as $U M F(\tilde{A})$ or $\bar{\mu}_{\tilde{A}} ; \underline{\mu}_{\tilde{A}}(x)$ - the value of the lower membership function, denoted as $\operatorname{LMF}(\tilde{A})$ or $\underline{\mu}_{\tilde{A}}$.

The nested interval FST2 $\tilde{A}_{e}$ for continuous (infinite) sets $X$ and $J_{x}$ is a set in which each primary variable $x \in X$ has only one secondary variable $u \in J_{x}$ (ie one value of the primary membership) with a corresponding secondary degree equal to 1 , that is:

$$
\tilde{A}=\int_{x \in X} \frac{\left[\frac{1}{u}\right]}{x}, u \in J_{x} \subseteq U=[0,1]
$$

A nested FST1 $A_{e}$ with power $N$ for discrete (finite) sets $X$ and $J_{x}$ is a set of pairs, where the first elements of the pair represent the corresponding primary variables, and the second elements are exactly the same value as $J_{x_{1}}, J_{x_{1}}, \ldots, J_{x_{N}}$, namely $u_{1}, u_{2}, \ldots, u_{N}$, i.e.:

$$
\tilde{A}=\sum_{j=1}^{N} \frac{u_{i}}{x_{i}}, u_{i} \in J_{x_{i}} \subseteq U=[0,1], x_{i} \in X .
$$

Comparing expressions (10) and (11), it is possible to represent the nested IFST2 through the elements of the nested FST1 as [8,9]:

$$
\tilde{A}_{e}=\frac{1}{A_{e}}
$$

Representation Theorem is considered in [8, 9], according to which IFST2 $\tilde{A}$ can be represented as a union of IFST2 nested in it, i.e.:

$$
\tilde{A}=\bigcup_{j=1}^{n} \tilde{A}_{e}^{j}
$$

where $n$ - the number of nested IFST2 $\left(\tilde{A}_{e}^{j}\right.$ is represented according to the expression (9)) $n=\prod_{i=1}^{N} M_{i} ; N-$ the number of values to which $X$ is sampled; $M_{i}$ - the number of values to which $J_{i}$ is sampled.

Representation of IFST2 as expression (13) is a representation of IFST2 by the wavy section.

By analogy with expression (13), the occupied area of uncertainty $F O U$ can be represented as:

$$
\operatorname{FOU}(\tilde{A})=\bigcup_{j=1}^{n} A_{e}^{j}
$$

By expression (14) and taking into account expression (13), IFST2 can be represented as follows:

$$
\tilde{A}=\bigcup_{j=1}^{n} \frac{1}{A_{e}^{j}}=\frac{1}{\bigcup_{j=1}^{n} A_{e}^{j}} \equiv \frac{1}{\operatorname{FOU}(\tilde{A})}=\frac{1}{\bigcup_{\forall x \in X}\left[\bar{\mu}_{\tilde{A}}(x), \underline{\mu}_{\tilde{A}}(x)\right]}
$$

In fig. 1 presents the final structure of the modified fuzzy Wang-Mendel neural network based on the use of IFST2 and with $\mathrm{k}$ outputs by the number of recognized classes (subclasses) of objects.

In this case, the output signal of the modified WangMendel network can be calculated by the following series of expressions:

$$
\begin{aligned}
\bar{y}_{\text {class }}(x)= & \frac{\sum_{j=1}^{M} \bar{c}_{i} \prod_{j=1}^{N}\left(x_{j}\right)}{\sum_{i=1}^{M} \prod_{j=1}^{N} \bar{\mu}_{i j}\left(x_{j}\right)}, \\
\underline{y}_{\text {class }}(x)= & \frac{\sum_{j=1}^{M} \underline{c}_{i} \prod_{j=1}^{N} \underline{\mu}_{i j}\left(x_{j}\right)}{\sum_{i=1}^{M} \prod_{j=1}^{N} \underline{\mu}_{i j}\left(x_{j}\right)} .
\end{aligned}
$$




$$
Y=J_{x}^{\text {class }}=\left|\bar{y}_{\text {class }}(x), \underline{y}_{\text {class }}(x)\right|
$$

where $x_{j}$ is an input signal; $\bar{c}_{i}, \underline{c}_{i}$ is the center of the width of the upper and lower Gaussian function, which represents the membership function of a fuzzy set of rule conclusions; $\bar{\mu}_{i j}, \underline{\mu}_{i j}$ - the values of the upper and lower membership functions of the prerequisites of the rules; $J_{x}^{\text {class }}$ - the primary affiliation of the recognized class (subclass).

Thus, according to the representative theorem (by expression (15)), IFST2 is the union of all nested FST1, which cover its occupied area of uncertainty. The importance of this conclusion is as follows:

- first, the thesis that IFST2 is fully described (determined) by its FOU is confirmed;

- secondly, it is possible to use as operations on IFST2 the corresponding operations on FST1, which greatly simplifies the computational complexity of IFST2 for their implementation within the framework of the corresponding fuzzy logic systems. Therefore, the membership functions are used, which are fully described by the corresponding FOU, in which, in turn, the upper and lower limits can be represented by the Gaussian function according to the expression (2).

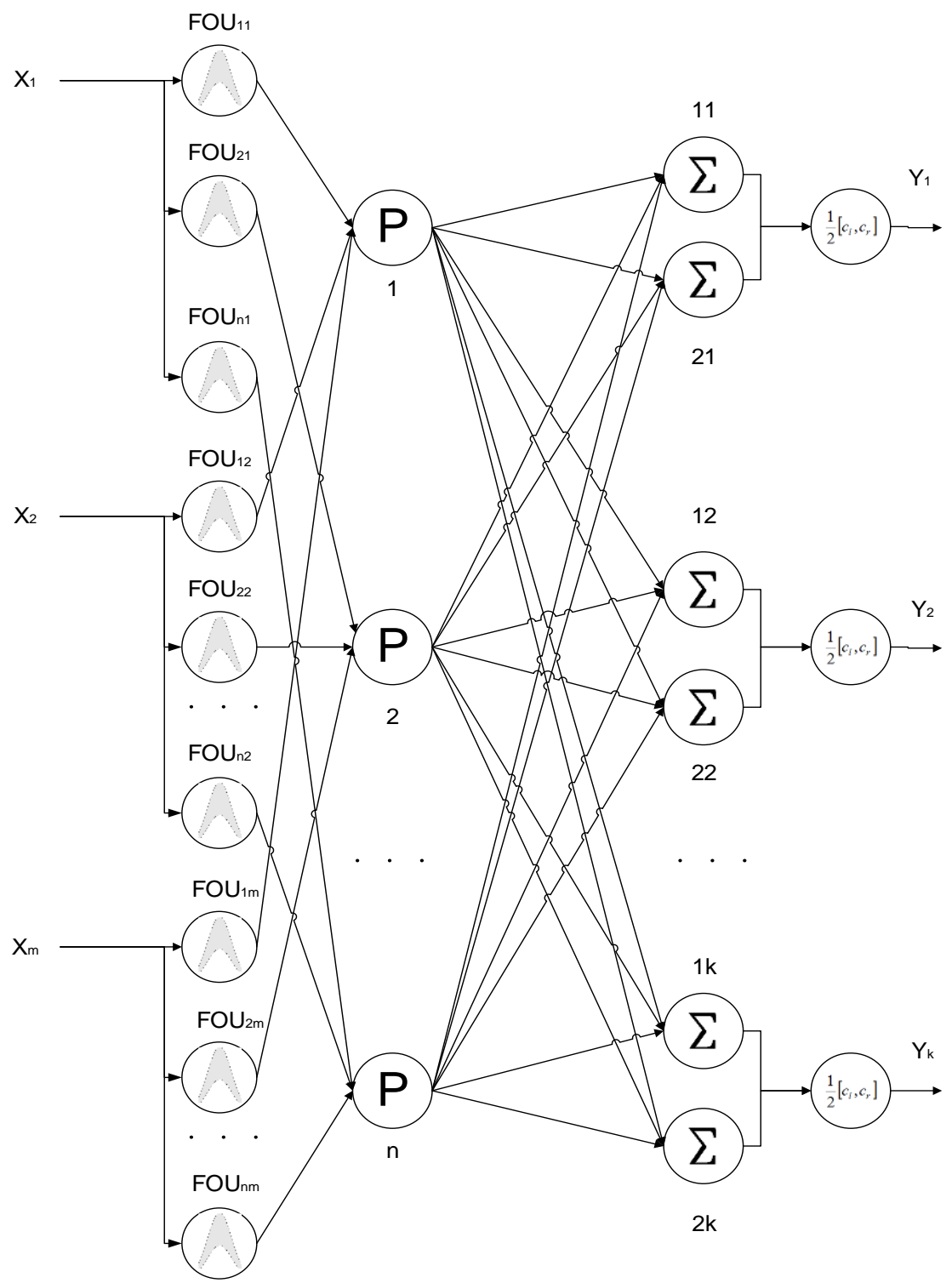

Fig. 1. The structure of the modified fuzzy neural production network of Wang-Mendel based on IFST2

This study identified two classes for recognition: urban and non-urban. Semantic segmentation is used as a basic method of recognition. Semantic (or semantic) image segmentation is the selection of areas in the image, each of which corresponds to a certain feature. In general, the tasks of semantic segmentation are difficult to algorithmize, so for image segmentation are now widely used deep neural networks, which show a fairly high accuracy of recognition of segmentation objects (this is a network based on U-Net auto encoder, where the classifier is proposed to use modified fuzzy Wang-Mendel neural network). The input data for the corresponding network are digital images of the urban environment, and the output data are considered to be the corresponding 
segmented images with the selection of pixels corresponding to two classes: urban structure and nonstructure.

\section{Conclusions}

Thus, the architecture of the modified convolutional neural network with respect to image segmentation (auto coder) U-net is proposed. In this case, as a classifier, the use of a modified fuzzy Wang-Mendel neural production network with respect to the pixel-by-pixel classification of certain objects is proposed. Also, IFST2 is used in this network instead of FST1.

The proposed IFST2, on the one hand, provide a formalization of more additional degrees of uncertainty compared to FST1, on the other hand, are "implemented" in the development of fuzzy systems (models) and have less computational complexity compared to FST2.

The use of the developed architecture will increase the accuracy of segmentation of urban structures on digital space and aerial photographs with automated monitoring of the urban environment.

\section{References}

1. Mishchenko, V. A. Mishchenko, V. A., Astakhova, I. F., Krasnoyarov, A. A. (2012), "Learning algorithm for the Wang-Mendel fuzzy neural network for recognizing handwritten characters in the work of the postal service" ["Algoritm obucheniya nechetkoy neyronnoy seti Vanga-Mendelya dlya raspoznavaniya rukopechatnykh simvolov v rabote pochtovoy sluzhby"], Bulletin of Voronezh State University. Series: System Analysis and Information Technologies, No. 1, P. 141-146.

2. "Semantic segmentation: a quick guide" ["Semanticheskaya segmentatsiya: kratkoye rukovodstvo"], available at : https://neurohive.io/ru/osnovy-data-science/semantic-segmention/.

3. Ronneberger, O., Fischer, P., Brox, T. (2015), "U-net: Convolutional networks for biomedical image segmentation", In International Conference on Medical image computing and computer-assisted intervention, Springer, P. 234-241.

4. Kuksa, P. P. "Analysis of neural network-fuzzy models" ["Analiz neyrosetevykh-nechetkikh modeley"], Moscow State Technical University, available at : http://pkuksa.org/ pkuksa/publications/nfm-analysis-c-0-sept-03.pdf

5. Kruglov, V. V., Dli, M. I., Golunov, R. Yu. (2001), Fuzzy logic and artificial neural networks [Nechetkaya logika $i$ iskusstvennyye neyronnyye seti], Fizmatlit, $224 \mathrm{p}$

6. Olizarenko, S. A., Kapranov, V. A., Safronov, R. V. (2016), "Development of a fuzzy convolutional neural network architecture for the recognition of compact (point) objects in a digital aerial photograph" ["Rozrobka arkhitektury nechitkoyi $z$-hortochnoyi neyronnoyi merezhi dlya rozpiznavannya kompaktnykh (tochkovykh) ob"yektiv na tsyfrovomu aerofotoznimku"], Systems of Arms and Military Equipment, Kharkiv, HUPS, Issue 4 (48), P. 38-41.

7. Ivanov, E. S., Tishchenko, I. P., Vinogradov, A. N. (2019), "Segmentation of multispectral images using convolutional neural networks" ["Segmentatsiya mul'tispektral'nykh snimkov s primeneniyem svortochnykh neyronnykh setey"], Modern problems of remote sensing of the Earth from space, Vol. 16, No. 1, P. 25-34.

8. Soloviev, R. A., Telpukhov, D. V., Kustov, A. G. (2017), "Automatic segmentation of satellite images based on a modified convolutional neural network UNET" ["Avtomaticheskaya segmentatsiya sputnikovykh snimkov na baze modifitsirovannoy svortochnoy neyronnoy seti UNET"], Engineering Bulletin of the Don, No. 4, available at: ivdon.ru/ru/magazine/archive/n4y2017/4433

9. Long, J., Shelhamer, E., Darrell, T. (2015), "Fully Convolutional Networks for Semantic Segmentation", Computer Vision and Pattern Recognition (cs.CV), available at : https://arxiv.org/abs/1411.4038

10. Gordienko, A. S. (2015), "The use of index images for detecting changes in space images of different times" ["Primeneniye indeksnykh izobrazheniy pri vyyavlenii izmeneniy po raznovremennym kosmicheskim snimkam"], Interexpo GEO-Siberia-2015. XI Int. scientific. Congr. : Int. scientific. conf. "Remote sensing methods of the Earth and photogrammetry, environmental monitoring, geoecology": collection of articles. materials in 2 volumes (Novosibirsk, April 13-25, 2015), Novosibirsk : SGUGiT, Vol. 1, P. 67-70. 11. Gavrilova, T. A., Khoroshevsky, V. F. (2000), Knowledge bases of intelligent systems [Bazy znaniy intellektual'nykh sistem], $\mathrm{SPb}$ : : Peter, $384 \mathrm{p}$.

12. Iskander, Yu. M. (2003), Creation of knowledge bases of intelligent systems [Sozdaniye baz znaniy intellektual'nykh sistem], Ministry of Defense of the Russian Federation, 233 p.

13. Milletari, F., Navab, N., Ahmadi, S. (2016), "V-Net: Fully Convolutional Neural Networks for Volumetric Medical Image Segmentation", 2016 Fourth International Conference on 3D Vision (3DV), Stanford, CA, P. 565-57.

14. Takagi, T., Sugeno, M. (1985), "Fuzzy Identification of Systems and Its Applications to Modeling and Control", IEEE Trans. on Systems, Man, and Cybernetics, Vol. 15, No. 1, P. 116-132.

15. Mendel, J. M., Hagras, H., John, R. I. "Standard Background Material About Interval Type-2 Fuzzy Logic Systems", IEEE CIS Standards Committee, available at : http://ieee-cis.org/technical/standards.

Received 03.08.2020

\section{Відомості про авторів / Сведения об авторах / About the Authors}

Коломійцев Олексій Володимирович - Заслужений винахідник України, доктор технічних наук, старший науковий співробітник, Національний технічний університет "Харківський політехнічний інститут", професор кафедри обчислювальної техніки та програмування, Харків, Україна; email: Alexus_k@ukr.net; ORCID: https://orcid.org/0000-00018228-8404.

Коломийцев Алексей Владимирович - Заслуженный изобретатель Украины, доктор технических наук, старший научный сотрудник, Национальный технический университет "Харьковский политехнический институт", профессор кафедры вычислительной техники и программирования, Харьков, Украина.

Kolomiitsev Oleksii - Honored Inventor of Ukraine, Doctor of Sciences (Engineering), Senior Research, National Technical University is the "Kharkiv Polytechnic Institute", Professor of the Department of Computing Engineering and Programming, Kharkiv, Ukraine. 
Пустоваров Володимир Володимирович - здобувач наукового ступеня кандидата технічних наук, Харківське представництво генерального замовника - Державне космічне агентство України, начальник групи, Харків, Україна; email: pustovarov78volodymyr@gmail.com; ORCID: https://orcid.org/0000-0003-3944-5771.

Пустоваров Владимир Владимирович - соискатель научной степени кандидата технических наук, Харьковское представительство генерального заказчика - Государственное космическое агентство Украины, начальник группы, Харьков, Украина.

Pustovarov Volodymyr - Bread-Winner of Scientific Degree of PhD of Engineering Sciences, Kharkov Representative Office of General Customer - The State Space Agency of Ukraine, Chief of Group, Kharkiv, Ukraine.

\title{
ФОРМАЛЬНЕ ПРЕДСТАВЛЕННЯ ПРОЦЕСУ ПОПККСЛЬНОЇ КЛАСИФІКАЦЇ̈ З ВИКОРИСТАННЯМ МОДИФІКОВАНОЇ НЕЙРОННОЇ МЕРЕЖІ ВАНГА- МЕНДЕЛЯ
}

Предметом дослідження в статті $є$ процеси формалізації задачі попиксельної класифікації з використанням модифікованої нечіткої нейронної продукційної мережі Ванга-Менделя для сегментації міських будов при автоматизованому аналізі космічних та аерофотознімків території міста. Мета роботи - розробка архітектури модифікованої нечіткої нейронної продукційної мережі Ванга-Менделя у якості класифікатора для сегментації зображень для підвищення значень оперативності та достовірності міського моніторингу. В статті вирішуються наступні завдання: аналіз можливостей модифікації мережі Ванга-Менделя на основі подання функцій приналежності в термінах інтервальних нечітких множин другого типу (IHMT2) і реалізація операцій фазифікації, агрегування і активації з використанням операцій на IHМT2, розробка архітектури модифікованої нечіткої нейронної продукційної мережі Ванга-Менделя у якості класифікатора для сегментації зображень. Використовуються такі методи та моделі: методи та моделі теорії нечітких множин (нечітка нейронна мережа Ванга-Менделя, інтервальні нечіткі множини другого типу), методи та моделі методології глибокого навчання (згорткова нейронна мережа для сегментації зображень (автокодувальник) U-net). Отримано наступні результати: запропоновано використання нечіткої нейронної мережі Ванга-Менделя в якості класифікатора модифікованого декодера UNet на основі подання функцій приналежності в IHMT2 і реалізація операцій фазифікації, агрегування і активації 3 використанням операцій на IHМТ2; введення додаткової операції приведення типу в шарі дефаззіфікації вихідної змінної на основі класичного методу центру тяжіння (centroid); введення декількох виходів мережі для розпізнавання відповідної кількості класів (підкласів) предметної області. Для цього третій шар представляється як набір 3 декількох пар нейронів суматорів, а четвертий реалізує кілька нейронів-нормализаторів, кількість яких відповідає кількості пар третього шару. Висновок: застосування у архітектурі згорткової нейронної мережі для сегментації зображень U-net у якості класифікатора модифікованої нечіткої нейронної продукційної мережі Ванга-Менделя забезпечить додаткове підвищення точності попіксельної класифікації визначених об'єктів. Замість нечітких множин першого типу (НМТ1) в даній мережі використовуються IHMT2. Запропоновані IHMT2, з одного боку, забезпечують формалізацію більшої кількості додаткових ступенів невизначеності в порівнянні з НMT1, з іншого боку, є такими, що "реалізовуються" при розробці нечітких систем (моделей) і мають меншу обчислювальну складність, у порівнянні з нечіткими множинами другого типу (НMT2), модель.

Ключові слова: сегментація; класифікація; нечітка множина другого типу; нечітка нейронна мережа; продукційна

\section{ФОРМАЛЬНОЕ ПРЕДСТАВЛЕНИЕ ПРОЦЕССА ПОПИКСЕЛЬНОЙ КЛАССИФИКАЦИИ С ИСПОЛЬЗОВАНИЕМ МОДИФИЦИРОВАННОЙ НЕЙРОННОЙ СЕТИ ВАНГА-МЕНДЕЛЯ}

\begin{abstract}
Предметом исследования в статье являются процессы формализации задачи попиксельной классификации с использованием модифицированной нечеткой нейронной продукционной сети Ванга-Менделя для сегментации городских строений при автоматизированном анализе космических и аэрофотоснимков территории города. Цель работы - разработка архитектуры модифицированной нечеткой нейронной продукционной сети Ванга-Менделя в качестве классификатора для сегментации изображений для повышения значений оперативности и достоверности городского мониторинга. В статье решаются следующие задачи: анализ возможностей модификации сети Ванга-Менделя на основе представления функций принадлежности в терминах интервальных нечетких множеств второго типа (IHMT2) и реализация операций фазификации, агрегирование и активации с использованием операций на IHMT2, разработка архитектуры модифицированной нечеткой нейронной продукционной сети Ванга-Менделя в качестве классификатора для сегментации изображений. Используются такие методы и модели: методы и модели теории нечетких множеств (нечеткая нейронная сеть Ванга-Менделя, интервальные нечеткие множества второго типа), методы и модели методологии глубокой учебы (сверточная нейронная сеть для сегментации изображений (автокодировщик) U-Net). Получены следующие результаты: предложено использование нечеткой нейронной сети Ванга-Менделя в качестве классификатора модифицированного декодера U-Net на основе представления функций принадлежности в IHMT2 и реализация операций фазификации, агрегирования и активации с использованием операций на IHMT2; введение дополнительной операции приведения типа в слое дефазификации исходной переменной на основе классического метода центра тяжести (centroid); введение нескольких выходов сети для распознавания соответствующего количества классов (подклассов) предметной области. Для этого третий слой представляется как набор из нескольких пар нейронов сумматоров, а четвертый реализует несколько нейронов-нормализаторов, количество которых отвечает количеству пар третьего слоя. Вывод: применение в архитектуре сверточной нейронной сети для сегментации изображений U-Net в качестве классификатора модифицированной нечеткой нейронной продукционной сети Ванга-Менделя обеспечит дополнительное повышение точности попиксельной классификации определенных объектов. Вместо нечетких множеств первого типа (HMT1) в данной сети используются IHMT2. Предложены IHMT2, с одной стороны, обеспечивают формализацию большего количества дополнительных степеней неопределенности по сравнению с НМТ1, с другой стороны,
\end{abstract}


являются такими, которые "реализовываются" при разработке нечетких систем (моделей) и имеют меньшую вычислительную сложность по сравнению с нечеткими множествами второго типа (HМT2).

Ключевые слова: сегментация; классификация; нечеткое множество второго типа; нечеткая нейронная сеть; продукционная модель.

\section{Бібліографічні описи / Bibliographic descriptions}

Коломійцев О. В., Пустоваров В. В. Формальне представлення процесу попіксельної класифікації з використанням модифікованої нейронної мережі Ванга-Менделя. Сучасний стан наукових досліджень та технологій в промисловості. 2020. № 3 (13). C. 122-128. DOI: https://doi.org/10.30837/ITSSI.2020.13.1.122.

Kolomiitsev, O., Pustovarov, V. (2020), "Formal representation of the pixel-by-pie124l classification process using a modified Wang-Mendel neural network", Innovative Technologies and Scientific Solutions for Industries, No. 3 (13), P. 122-128. DOI: https://doi.org/10.30837/ITSSI.2020.13.122. 